\title{
Description of Acculturation Stress of Papuan Students who are ongoing Class at the University of Sumatra Utara
}

\author{
Nunung F.Sitepuํㅜ, Chyntia Septiani Sinaga ${ }^{2}$ \\ Medical Surgical Department ${ }^{1}$ \\ Deli Husada Nursing College Delitua ${ }^{1}$ \\ Faculty of Nursing University of Sumatera Utara ${ }^{2}$ \\ nunung.febriany@gmail.com
}

\begin{abstract}
Papuan students who are ongoing class at the University of Sumatera Utara are Papua affirmation students and West Papua who had opportunity to continue their education into the State University through affirmation Scholarship Program of Higher Education in cooperation with The Ministry of Education and Culture and research and technology of Higher Education. In different cultures and new environment allow them to acculturate and in its process have variety of challenges, obstacles and difficulties experienced by Papua students. That is having adaptation to new potential culture lead acculturation stress. This study aims to know the acculturation stress of Papua students who are ongoing class at the University of North Sumatra. This study used descriptive design, with 56 Papua students as sample. This study used total sampling techniques and questionnaires as instrument. The result of this study showed that Papua students experienced acculturation stress in low category is 52 people (92.9\%) and high category is 4 people (7.1\%). This result expected to the University, particular for nursing education institutions to provide introduction about culture for new Papua students Affirmations and West Papua when have matriculation so that making them easier in adapting and to anticipate the acculturation stress.
\end{abstract}

Keywords: Acculturation Stress, Papua Students

\section{INTRODUCTION}

Today, equitable development in Indonesia has been realized through scholarship programs offered by companies and institutions by providing cost free education and scholarships for outstanding students increase their academic potential. Scholarships not only be enjoyed by students from big cities only, but also has now emerged a scholarship program that facilitates children of the nation, particularly those in outlying areas that are difficult to access (Ariani, 2015). Affirmations Higher Education Scholarships be a solution for the student of Papuans to continue higher education at State Universities (Government University) in Indonesia. The program is based on Presidential Decree Number 65 Year 2011 on the Acceleration of Development of Papua and West Papua, which reads "Unit for the Acceleration of Development of Papua and West
Papua, hereinafter referred UP4B, is the institution established to support coordination, facilitating and controlling the implementation of the Acceleration development of Papua and West Papua". Scholarships Affirmations Higher Education is a scholarship in cooperation Kemdikbud, Unit for the Acceleration of Development of Papua and West Papua (UP4B), and the Council of the Rector of State Indonesia, in order to enhance human resources in Papua and West Papua (Source: official website UP4B http: / /up4b.go.id).

The implications of the existence of this scholarship program requires the students Papuans from Papua and live in areas where the students will continue their education at public universities throughout Indonesia. This scholarship is held starting in 2012 in collaboration with 32 state universities in Indonesia. In 2014 the number of Universities 
which joined the scholarship program have added to 39 state universities that are scattered throughout Indonesia (Source: Official website UP4B http://up4b.go.id). University of Sumatera Utara (USU) is one of 39 State Universities which receives students from Papua through a scholarship program affirmation of Higher Education. Since the year 2012 to new admissions in 2015 there were 58 active Papuan students studying at USU. All students accepted through national selection path. Student from Papua receiving scholarships affirmation of Higher Education in USU had to move and live a new life as students at USU. The presence of Papua students at USU give new nuances in the world of college education at USU. Papua students begin class 2012 to class of 2015 settled at USU with all the different sociocultural aspects of a student's home or to college Papua. Stay and live in different societies socially and culturally raises the possibility of a certain psychological social impact. One of the socio-psychological effects that usually happens is adapting to the new environment. Differences in language, values, and habits, beyond the issue of geographical climate, become the main obstacle (Wijanarko \& Safiq, 2013). Therefore many things are perceived by students from Papua changed from daily in Papua. Start any divergence customs, food, beverage, language, and social environment are different. Ariani (2015) stated the qualitative research that Papua students who received scholarships affirmation of Higher Education in University of
Semarang experiencing socio-cultural barriers when studying at that places. The result shows the barriers experienced by Papua students are: 1) lack of knowledge and provision of Papuan students know about that University; 2) differences in food; 3) differences in style dressed; 4) Homesick; 5) stereotypes and discrimination; and 6) the language differences. Such constraints led to the psychological impact within their personal and social lives. Wijanarko \& Safiq (2013) concluded in their study that students who come from outside the island of Papua in Surabaya encounter various obstacles in adjusting. These obstacles are differences in language, physical characteristics, and cultural habits with local communities. This barrier shows psychological impact within their personal and social life. From interviews with the head researcher Affirmations Papua and West Papua at USU, that there are already two people who died in 2015 due to the perceived obstacles during the process of acculturation. Barriers perceived is the difference of food \& beverage accustomed as tasty eating traditional foods Papua (sago, cassava) so that when the field is not the appetite because it does not fit with the food in the field, also caused by the habit of drinking alcoholic beverages, and the language barrier also occurs against social so feel difficulty in communicating with the social to look for health services. The purpose of this study was to determine the stress of acculturation Papuan students who live lectures at the University of Sumatera Utara. 


\section{METHODS}

The study design used in this study is descriptive, using total sampling technique with a sample of 56 people. This research was conducted at the University of Sumatera Utara. The research was conducted in October 2015 and July 2016.

Table 1. Distribution of frequency and percentage of stress acculturation category Papuan students who are ongoing class at the University of Sumatera Utara

$$
(n=56) \text {. }
$$

\begin{tabular}{|c|c|c|c|c|c|c|}
\hline \multirow{2}{*}{ Year } & \multicolumn{3}{|c|}{ Stress Acculturation } & \multicolumn{2}{c|}{ Totally } \\
\cline { 2 - 7 } & Low & $\%$ & High & $\%$ & $\mathrm{n}$ & $\%$ \\
\hline 2012 & 11 & 100 & 0 & 0 & 11 & 100 \\
\hline 2013 & 9 & 100 & 0 & 0 & 9 & 100 \\
\hline 2014 & 11 & $\begin{array}{c}73, \\
3\end{array}$ & 4 & 26, & 15 & 100 \\
& & & 7 & & \\
\hline 2015 & 21 & 100 & 0 & 0 & 21 & 100 \\
\hline Total & \multicolumn{9}{|c}{} & & $\mathbf{5 6}$ & $\mathbf{1 0 0}$ \\
\hline
\end{tabular}

Table 2. Distribution of frequency and percentage of acculturation stress crosstabs Papuan students who are ongoing class at the University of Sumatera Utara with gender $(n=56)$.

\begin{tabular}{|c|c|c|c|c|c|c|}
\hline \multirow{2}{*}{$\begin{array}{c}\text { Stress } \\
\text { Acculturation }\end{array}$} & \multicolumn{4}{|c|}{ Sex } & \multicolumn{2}{c|}{ Totally } \\
\cline { 2 - 7 } & Low & $\%$ & High & $\%$ & $\mathrm{n}$ & $\%$ \\
\hline Male & 23 & 41,1 & 3 & 5,3 & 26 & 46,4 \\
\hline Female & 29 & 51,8 & 1 & 1,8 & 30 & 53,6 \\
\hline Total & \multicolumn{4}{|c|}{} & $\mathbf{5 6}$ & $\mathbf{1 0 0}$ \\
\hline
\end{tabular}

The results found that the stress of acculturation of Papuan students in the low category of 52 people $(92.9 \%)$ consisted of 23 people (41.1\%) male sex and 29 people $(51.8 \%)$ were female, and stress acculturation Papuan students in the high category of 4 people $(7.1 \%)$ consists of $3(5.3 \%)$ sex male and 1 $(1.8 \%)$ were female.
Table 3. Distribution of frequency and percentage of acculturation stress crosstabs Papuan student who are ongoing class at the University of Sumatera Utara with age $(n=56)$.

\begin{tabular}{|c|c|c|c|c|c|c|}
\hline \multirow{2}{*}{ Age } & \multicolumn{4}{|c|}{ Stress Acculturations } & \multicolumn{2}{c|}{ Totally } \\
\cline { 2 - 7 } & Low & $\%$ & High & $\%$ & $\mathrm{n}$ & $\%$ \\
\hline 18 & 7 & 100 & 0 & 0 & 7 & 100 \\
\hline 19 & 13 & 92,85 & 1 & 7,15 & 14 & 100 \\
\hline 20 & 14 & 82,35 & 3 & 17,65 & 17 & 100 \\
\hline 21 & 9 & 100 & 0 & 0 & 9 & 100 \\
\hline 22 & 6 & 100 & 0 & 0 & 6 & 100 \\
\hline 23 & 2 & 100 & 0 & 0 & 2 & 100 \\
\hline 24 & 1 & 100 & 0 & 0 & 1 & 100 \\
\hline Totally & & & & & $\mathbf{5 6}$ & $\mathbf{1 0 0}$ \\
\hline
\end{tabular}

The results found that the category of stress acculturation low at the age of 18 years were 7 people $(100 \%)$, at the age of 19 years were 13 (92.85\%), at the age of 20 years were $14(82.35 \%)$, by age 21 were 9 people $(100 \%)$, at the age of 22 years were 6 people $(100 \%)$, at the age of 23 years were 2 people $(100 \%)$, at the age of 24 years is $1(100 \%)$. The category of high acculturation stress are at the age of 19 years by 1 person $(7.15 \%)$ and at the age of 20 years as many as 3 people $(17.65 \%)$.

Table 4. Distribution of frequency and percentage of acculturation stress crosstabs Papuan students who are ongoing class at the University of Sumatera Utara with years $(n=56)$.

\begin{tabular}{|l|l|l|}
\hline $\begin{array}{l}\text { Stress Acculturation } \\
\text { variables Papuan } \\
\text { Students }\end{array}$ & Frequency & $\begin{array}{l}\text { Percentage } \\
(\%)\end{array}$ \\
\hline Low acculturation stress & 52 & 92,9 \\
\hline Acculturation stress high & 4 & 7,1 \\
\hline Total & $\mathbf{5 6}$ & $\mathbf{1 0 0}$ \\
\hline
\end{tabular}

The results found that the stress of acculturation of Papuan students in the low category consisted of 11 people $(100 \%)$ in years $2012,9(100 \%)$ in years, $2013,11(73.3 \%)$ in years 2014 , and 21 people $(100$ $\%)$ years 2015 . While the stress of acculturation Papuan students with high category, originated in years 2014 as many as four people (26.7\%). 


\section{DISCUSSION}

The research result obtained is that the majority of Papuan students who are ongoing class at the University of Sumatera Utara experienced acculturation stress with low category as many as 52 people (92.9\%), and only $4(7.1 \%)$ who experienced the stress of acculturation by category high. The results are in contrast to studies Hapsari \& Primastuti (2014) which states that the Papuan Students find it difficult to socialize in an environment of people who come from other areas, such as when the lecture he found it difficult to get a group to do the work, and even had to not get group and do it alone. However, the results also showed that there are some Papuan students who are ongoing class at the University of Sumatera Utara, perhaps because of the individual has not been able to adapt / acculturation low that marked the negative reactions they felt from the community and local students (who are not Papua) that making them easily tense (emotions) and more often prefer to gather and interact with the students with their ethnicity.

Based on the results stated that the respondents were female as many as 30 people $(53.6 \%)$ are subjected to low acculturation stress that as many as 29 people $(51.8 \%)$. These results are supported by previous studies which state that female students have better social skills to cope with the stress of acculturation / further compromise (Pacleb \& Collins, 2014). It shows that men have a higher risk for experiencing the stress of acculturation with the higher category than women. The results obtained are also supported by previous research which claimed that male students have a dominant trait that often cause conflicts of various cultures (acculturation stress and have low social skills than girls (Pacleb \& Collins, 2014). The age of teens rapid mental development occurred, mental development in their teens resulted in the ability of adolescents to hypothesizes anything related to his life and the environment also increases (Wong's \& Hockenberry, 2007). The results obtained also showed that the respondents in the first class of the year 2012 as many as 11 people $(100 \%)$ all have stress levels of acculturation low equal to the force in 2015 as many as 21 people $(100 \%)$ which is the first batch once exposed to a new environment that is entirely too this has the stress of low acculturation. The result showed that no significant differences in acculturation stress perceived by Papuan students in 2015 the newly exposed to the new environment. Results are inversely related to previous research that gets results that the environment is the highest factor of stress on students making up the first year in which students feel it difficult to adapt when entering a new environment and atmosphere (Nurmaningtyasih, 2015).

\section{CONCLUSION}

Papuan students who studying at USU mostly stressed acculturation with lower category which proves that they are able to socialize and have no pathological problem in running classes at USU and proved that studying in different places far to the cultural and living environment (especially those of USU ) does not significantly affect the stress of acculturation makes them high.. So, there are still some, that may be due to individual factors that have not been able to adapt / acculturation had less negative reaction from the public and local students (who are not Papua) that makes them feel uncomfortable marked with ease their tense (emotional) against negative reactions from students and the local community (which is not Papua) and the more often prefer to gather and interact with the students with their ethnic one (Papua).

\section{SUGGESTION}

For nursing education, especially nursing psychiatry and communities need to be given recognition culture to new students Affirmations Papua and West Papua at the time of matriculation to assist them in recognizing and adapting to the environment and a new culture and to minimize the stress of acculturation on new students Affirmations Papua and West Papua undergo classes at USU.

\section{Acknowledgment}

Thank you to University of Sumatera Utara for giving the author to conduct research on campus and facilitate to International proceeding. Beside, especially thank you to Faculty of Nursing University of Sumatera Utara for giving the author research with nursing student. 


\section{REFERENCES}

Ariani, N. (2015). Social Adaptation Strategy Papua Student Scholarship Cultural Affirmation of Higher Education (SISTER) in 2013 At the State University of Semarang. Semarang: Education Thesis Sociology and Anthropology.

Hapasari, A., \& Primastuti, E. (2014). Confidence Judging from the Papua Student Support Peers. Journal of Psychology Psikodimensia. Vol. 13 No. 1. Semarang: Catholic University Psychology Department.

Nurmaningtyasih, I. (2015). Student Stress UIN Maulana Malik Ibrahim Malang. Malang: Thesis Faculty of Psychology Department of Psychology.
Pacleb, S \& Collins J. (2014). The Relationship of Acculturation Stress and Leisure Satisfaction of Hispanic College Students. American International Journal of Contemporary Research. Vol.4, No. 4. United States of America. Source: website UP4B http://up4b.go.id

Wijanarko, E. \& Syafiq, M. (2013). Phenomenology Study: Adjusment Experiences of Papuan student in Surabaya, Journal Psychology: Theory and Aplicatioan. Vol 3 No 2

Wong's \& Hokenberry. (2007). Wong's Nursing Care og Infants and Children. (8 ed.). Canada: Mosby Elsevier. 